\title{
HISTORY CURRICULUM DEVELOPMENT MODEL TOWARDS NATION BUILDING OF MALAYSIA
}

\author{
Abdul Razaq Ahmad ${ }^{1}$ \\ Ahmad Rafaai Ayudin
}

\begin{abstract}
Malaysia is a heterogenic country as the nation is formed by multiracial. Thus, national stability and racial harmony are depending on how relationship among ethnics is enhanced and preserved in order to form a strong nation state. The government is fully aware that educational institutions are the most important disseminators of unity values in enhancing the nation of Malaysia. Schools are the main disseminators through curriculum development and evaluation towards values of unity and national integration, in restoring understanding on the nation and the country. The Curriculum Development Model is the foundation of the research proposal to serve as an implementation manual to inculcate values of unity through History Curriculum. The implementation involves five relevant constructs in defining curriculum, involving comprehensive efforts in providing students education, which are: (1) textual contents (text books) (2) pedagogical elements, (3) inculcation of values, (4) usage of teaching aids and (5) assessment. This research evaluates the relationship among the five constructs towards the elements of racial unity in establsihing the nation state of Malaysia, with the demise of prejudiced and racial gap. The comprehensive curriculum empathizes on the importance of holistic unity components to ensure that the inculcation of values is successfully done through multiple dimensions.
\end{abstract}

Key words: content of textbook, pedagogy, teaching aids and assessment.

\section{Introduction}

History education was declared as a compulsory basic education due to the elements of people and society in the subject. Wang Gangwu (1964) stated the importance of learning History, as followed:

... we teach history because it is an essential part of the education of theyoung people of the most countries and all modern nations and I will take for granted that

1 Prof. Dr. Madya. Abdul Razaq Ahmad is Senior Lecturer of Faculty of Education, National University of Malaysia. Ahmad Rafaai Ayudin, PhD is a History teacher with 12 years of experiences at secondary school in Malaysia. This Article has been reviewed by Prof.Dato.Dr.Qasim Ahmad (UiTM Malaysia), Dr. Nana Supriatna, M.Ed (Indonesia University of Education, and Prof. Dadang Supardan, M.Pd ((Indonesia University of Education). 
it is a subject which is taught in school and universities and something educations are agreed upon as a basic education for everybody."

Due to that, the policy of introducing History curriculum as the core subject in the KBSM for all students regardless of school streaming, accross races, religions and cultures is relevant to the current situation. All races in Malaysia are aware and agreed that national unity is the main force to transform the nation toward achieving success.

The Malaysian society had experienced a long transformational process since the independency of Tanah Melayu in 1957 until now. Present achievements are the implications of social and racial tolerance by accepting one another and understanding cultural differences as well as eliminating racial prejudice and the ethos of ethic centric. The History subject is seen by the Government as the perfect vessel to enhance students' understanding on the background of the societies and multicultural of the nation, with the hope that the values of patriotism, nationalism and national unity would become part of the students, with the intention to establish the identity of satu bangsa, satu negara (one nation, one country) without the gloom of racial issues.

However, the content of History curriculum which prone to malaycentric, malayculture and malayfeudal does not help in disseminating and inculcating values of unity, in fact it creates problems and challenges due to:

1. cultural elements of the non-Malay ethnics are still parts of hidden curriculum and vague which need to be presented based on teachers' talents and creativity.

2. teachers are under pressured due to exam orientation in teaching, which neglecting the efforts to inculcate values

3. teaching methods are still static and conventionally done, in which teachers are depending on text books and lack of learning activities to encourage socialization among the multiracial

In the efforts to disseminate and establish awareness among students on satu bangsa, satu negara, teachers need to create a curriculum-based framework for unity and integration agendas. The teachers can then, enrich the framework with additional inputs and with the use of multiple resources. This means, in the efforts of establishing unity, teaching should not be focused solely on the content of the text books but on other effective elements as follow:

1. Pedagogical elements as part of teaching History strategies

2. Teaching steps to inculcate values

3. Usage of teaching aids to facilitate students' learning, understanding and appreciation and

4. assessment process to indentify achievement levels and changes in students' behaviours

The 10 essential values of unity to be developed and inculcated in students are : racial tolerance, practicing national identity, proud to be Malaysians, preserving uniqueness of multicultural, accepting differences, cultural understanding, 
acknowledging similarities and eliminating prejudice. The overall picture of the relationship between curriculum and elements of unity is as below

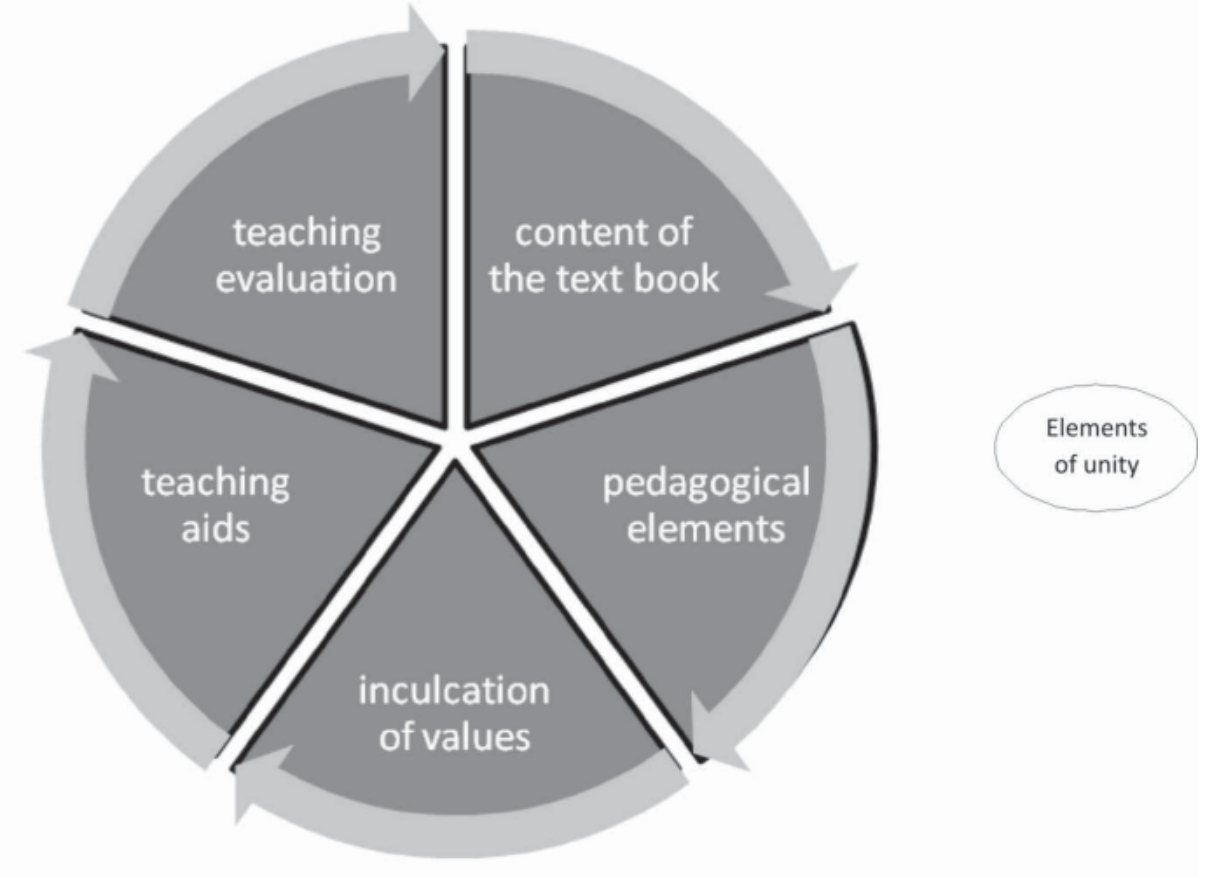

Figure 4.1 curriculum and elements of unity

Based on Figure 4.1, this is the curriculum development model towards the desired unity to be developed in the activities of teaching and learning History. It is a circle of chains among the components with the core implementation is to inculcate elements of unity.

\section{Theoretical foundation}

In terms of the contents of History subject, it was found that there are lots of weaknesses in teachers' efforts to nurture and strengthen unity. This is due to the fact that the contents are prone to political compared to debates on society and values of unity. Lessons for form 1 and 2 are lacking of segments especially provided for values of unity. Consequently, students are not exposed to current situations. Even though racial cooperation is slightly touched in form 3 lessons, it is merely about politics and election. Contents of the curriculum should be based on comprehensive aspects without certain segmentation and fragmentation which would hamper teachers' efforts to inculcate values of unity and strengthen the spirit of 1Malaysia.

After a decade of independency and in line with the Malaysian context, the national agenda has shifted from unity to integration, which is a step higher than unity, in the hope to integrate all cultural values of the plural society in a heterogenic lifestyle. And such, unity is no longer seen as a formal social 
relationship, but beyond the normal life's scope through cultural socialization of ethnics in Malaysia's own cultural climate. Thus, there are impertinent needs to establish mutual respect, mutual understanding and self-awareness through soul-searching on self-origins of all Malaysians.

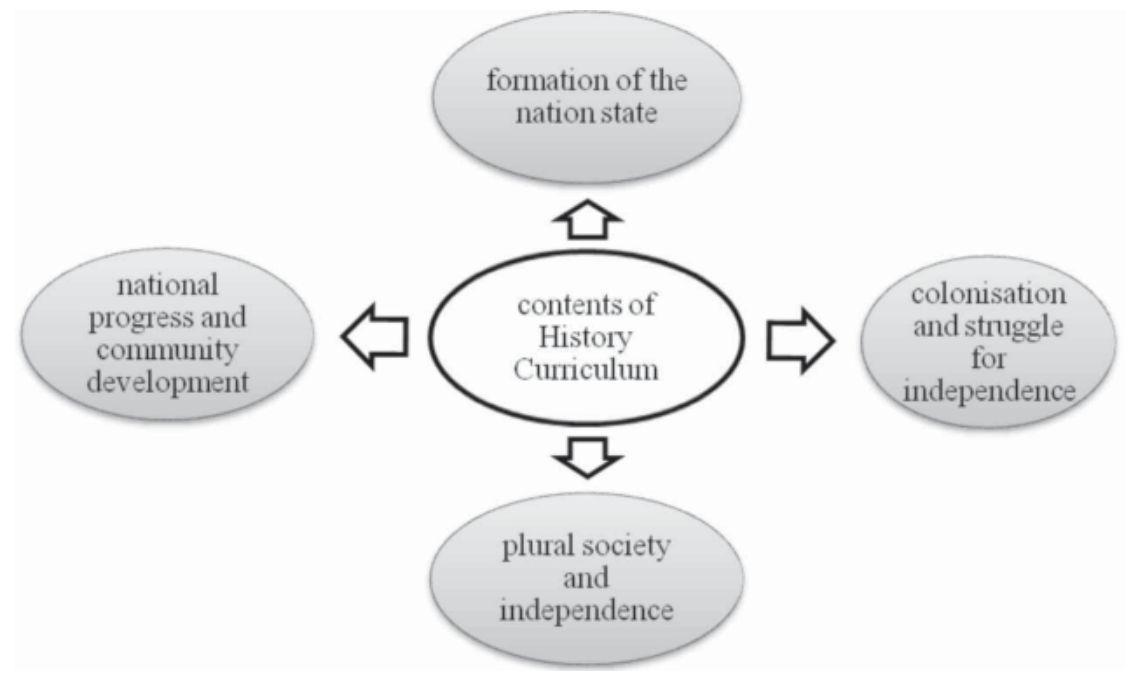

Figure 4.2: Proposal - Contents of History Curriculum for Lower Secondary

Lower secondary pupils are at the best phase for the purpose of establishing values for unity and the 1 Malaysia spirit, and thus a comprehensive understanding on the formation of the nation-state, the filling of independence and community development should be prioritized to establish the minds and characters of Malaysian ethos through History curriculum. Whereas, a deeper understanding on politics, economics and social would then be continued at the upper secondary level.

Cultural education in the History subject would introduce Malaysia as a plural society which is rich with ethnical cultures, in the hope to create mutual understanding and eliminate prejudgement. History subject would be able to create awareness on the civilization heritage and national development progress as long as unity and racial integration are the ground policies. History discussion on the plural society and values of unity in terms of politics, economics and social would be more effective if they are done through History curriculum (Hussein Ahmad 2000).

History is the most valuable for students in understanding their own nationstate (J awan 1977). Hence, researchers had realised a significant gap in the segments and fragments of the lower secondary History subject in fulfilling the term of unity and national integration values. And such, reshuffling and researching are needed to be done to strengthen the contents of lower secondary History curriculum as the main vessel and channel towards unity. This can be a huge help in realising the mission and vision of inculcating unity and national integration among the students. 
A research done by Furnival (1956), found that the third world countries experienced post-independence dilemma due to "divide and rule" policy imposed by the colonists. Such policy resulted in racial polarisation and segregation which then evoked prejudiceand social conflicts dueto narrow-minded communities and lack of racial interaction. According to Furnival, such philosophy had reaffirmed and re-established pluralism or a kind of multiracial society which " mix but do not assimilate', in other words they were together without mutual understanding and mutual acceptance.

According to Omar Hashim. (1992), the Malaysian society inclined to a kind of functional relationship rather than emphatatic. In other words, the relationship was confined in the office, market and working places, but interaction beyond those areas was very rare. One of the reasons identified was that discussion in the History curriculum was mainly on politics rather than social issues. Due to that kind of relationship, unity is only formed in a small and narrow social context as the communities are still inclined towards their own racial entity.

History teachers should use all of their competencies and practice an interesting pedagogy to engage students' prior knowledge, current knowledge and social reality as their foundation in organising learning activities. This is to providea meaningful and successful experience with the aim to indirectly improve the elements of unity through multiple techniques and interaction in a creative teaching and learning environment.

Figure 4.3 as presented below shows the five main components in developing curriculum. The curriculum is not solely on the subject matters but also refers to the whole supporting factors of educational process and developing students' potentials. The whole picture is shown in the component of planning learning experiences. In this research, History curriculum development is focussing on racial unity.

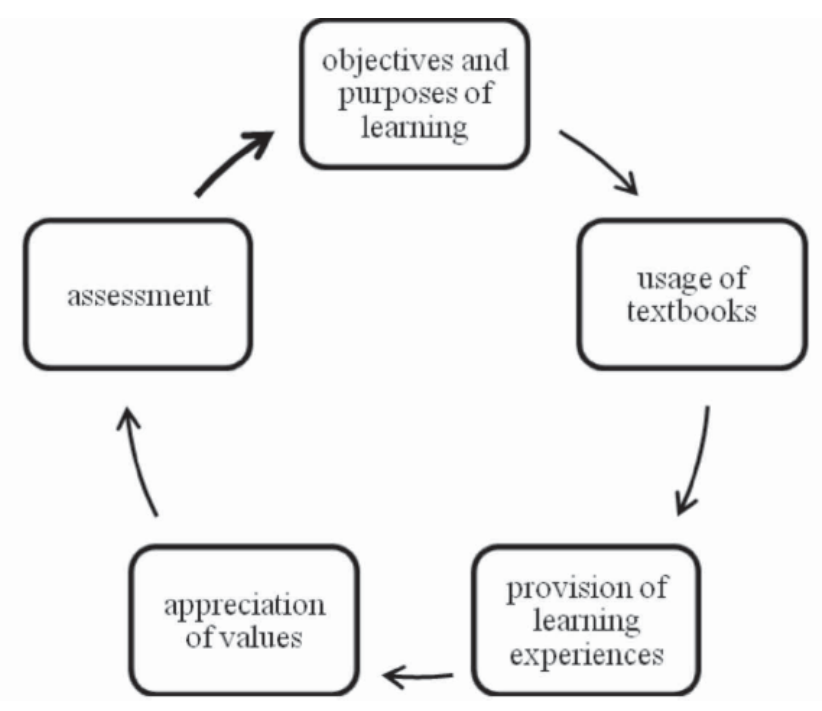

Figure 4.3: The Curriculum Components 
This study is aimed to develop a comprehensive History curriculum as the main vessel in strengthening values and as the best channel for racial unity. Theories on curriculum development and national unity were referred in order to establish and build the research conceptual framework.

\section{Research Conceptual Framework}

This study is based on the research conceptual framework as discussed below. It involves several independence variables as the main curriculum components in enhancing students' practice. The variables are zones, gender, races, streaming, parents' incomes and occupations. Due to those variables, the study was done at four different zones - north, south, central and east.

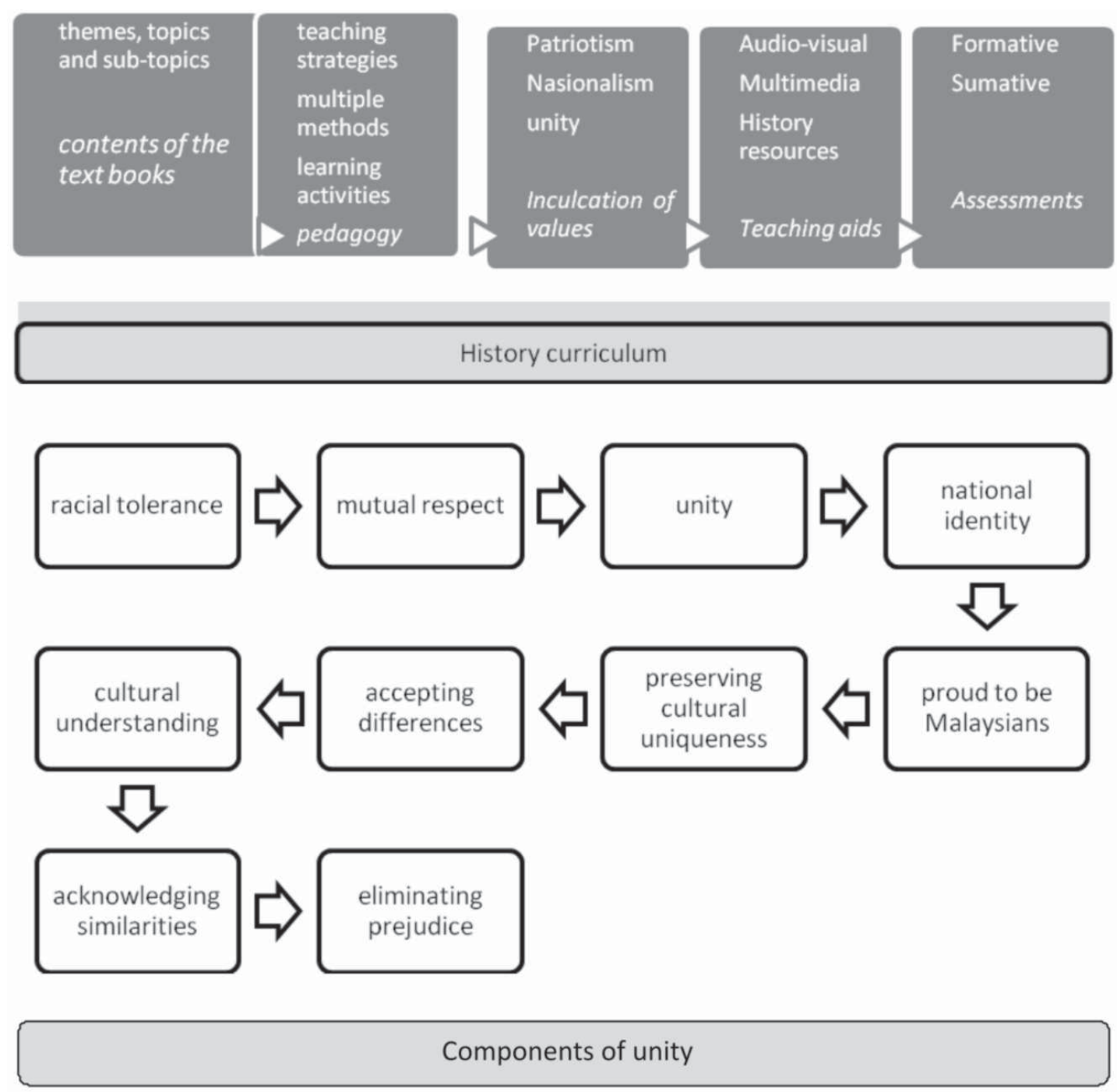

Figure 4.4 Research Conceptual Framework 


\section{METHODOLOGY}

\section{Samples}

This is a descriptive study and questionnaire was used as the main instrument to collect the research data. This is also a quantitave research by using a survey technique. Thetotal of samples is $\mathrm{N}=864$ of form fourstudents. Theindependence variables are zones, gender, races, streaming, parents' incomes and occupations

\section{Instrument}

The questionnaire was designed by using 5-points likert scale which consisted of seven parts of components: Part A-demographic background, Part B- contents of History text book, Part C- History pedagogy, Part D- inculcation of values, Part E- teaching aids, Part F- History assessment and Part G- racial unity

\section{Teachers' interview}

A pre-structured interview was used to get better answers (Suchman, 1967). Information gathered from the interview is very important in order to get teachers' opinions on the implementation of certain approaches in teaching History and to find their effects on students' behaviours.

\section{RESEARCH FINDINGS}

\section{Research question 1}

What is the level of students' perceptions on the components of curriculum, which are: contents of History text book, History pedagogy, inculcation of values, teaching aids, and History assessment towards racial unity?

Table 4.1 Mean level of students' perception towards components of history curriculum

\begin{tabular}{|l|c|c|c|}
\hline Components & Mean & S.D & level \\
\hline Contents of the text book & 3.79 & 0.64 & High \\
\hline Pedagogical elements & 3.63 & 0.73 & average \\
\hline Inculcation of values & 3.93 & 0.83 & high \\
\hline Teaching aids & 3.63 & 0.80 & average \\
\hline Assessments & 3.64 & 0.79 & average \\
\hline
\end{tabular}

Based on Table 1 above, the level of students' perception towards the components of text book contents and inculcation of values are high compared to pedagogical elements, teaching aids and assessments, which are still average. This finding shows that students depend on the content of the text book as the element for unity. They also agree that national integration values are disseminated by 
teachers, even though pedagogical practices and the usage of teaching aids are still average. This also confirms that teachers' determination and commitment in activating the teaching and learning process do play significant roles toward unity and national integration among students.

\section{Research question 2}

\section{What is students' perception on racial unity component?}

Finding of the research shows that the level of students' perception towards component of racial unity in overall is high with the mean score of 3.92 and s.d = 0.81 . The level of each and every component is high, which indicates that students are aware of the needs for racial unity and are having a mutual relationship. However, the role of History curriculum is needed to establish and strengthen racial unity.

\section{Research question 3}

Is there any significant difference of students' perceptions towards the components of curriculum: contents of History text book, History pedagogy, inculcation of values, teaching aids and assessment based on zones?

The overview of the question is as below:
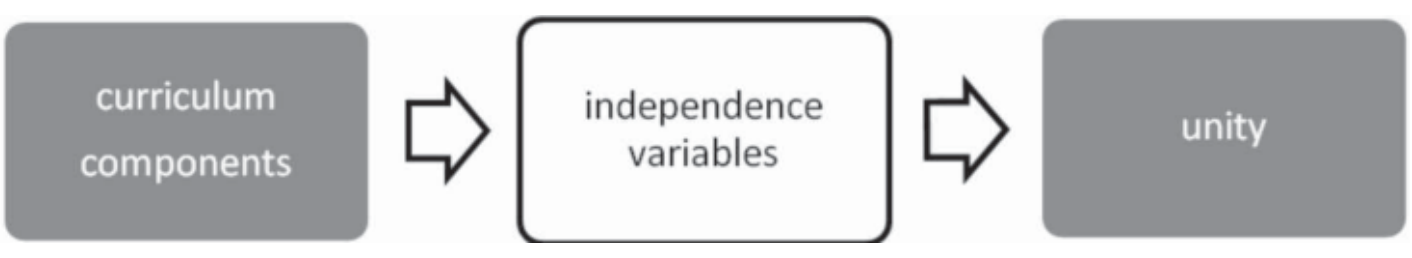

Figure 4.5: The research on differences of curriculum components towards elements of unity

From the survey, it is found that students from the south zone achieved high score on components of text book content, pedagogical elements, inculcation of values and assessment. Whereas, students from the east zone scored higher on teaching aids component. As a conclusion, there is a significant difference on curriculum component between students based on zones (living environment)

\section{Research question 4}

Is there any significant difference of students' perceptions towards the components of curriculum: contents of History text book, History pedagogy, inculcation of values, teaching aids and assessment based on gender? 
Table 4.2: Result of t-test based on gender

\begin{tabular}{|c|c|c|c|c|c|c|c|}
\hline Curriculum & & & & Standard & & & \\
\hline components & Gender & $\mathrm{N}$ & Mean & Deviation & $\mathrm{t}$ & df & Sig. \\
\hline Contents of History text & Males & 538 & 3.68 & 0.66 & -5.78 & 1127 & 0.000 \\
\hline book & Females & 591 & 3.89 & 0.60 & & & \\
\hline History pedagogy & Males & 538 & 3.54 & 0.75 & -3.97 & 1127 & 0.000 \\
\hline & Females & 591 & 3.71 & 0.70 & & & \\
\hline Inculcation of values & Males & 538 & 3.77 & 0.88 & -6.42 & 1127 & 0.000 \\
\hline & Females & 591 & 4.08 & 0.74 & & & \\
\hline Teaching aids & Males & 538 & 3.55 & 0.83 & -3.06 & 1127 & 0.002 \\
\hline & Females & 591 & 3.70 & 0.77 & & & \\
\hline Assessment & Males & 538 & 3.54 & 0.83 & -3.99 & 1127 & 0.000 \\
\hline & Females & 591 & 3.73 & 0.75 & & & \\
\hline
\end{tabular}

Result of t-test above shows that there is a significant difference on curriculum components based on gendertowardsall elements of components. This indicates changes and improvement from the aspects of understanding, thinking and appreciation of students through all of the curriculum components.

\section{Research question 5}

Is there any significant difference of students' perceptions towards the components of curriculum: contents of History text book, History pedagogy, inculcation of values, teaching aids, and assessment based on races?

The finding shows the mean score for the Malay students is high in all of the curriculum components compared to the Chinese and Indian students. Indian students show a better perception in contrast with the Chinese students. This indicates that the Indian students are more interested towards History learning when compared with the Chinese students.

\section{Research question 6}

Is there any significant difference of students' perceptions towards the components of curriculum: contents of History text book, History pedagogy, inculcation of values, teaching aids, and assessment based on parents' incomes?

The finding shows that students whose parents with the incomes more than RM2000.00 have high perception on History curriculum components except on text book component. Students whose parents are at the lower incomes depend on the text book as the main teaching and learning resource. This shows that there is no significant difference of the contents of History text book component based on parents' incomes, with the F values $=2.48$ and sig $=0.084(p>0.05)$, whereas there is a significant difference of History pedagogical component based on parents' incomes $=2.48$ and sig $=0.084(\mathrm{p}>0.05)$. There is also a significant difference in terms of inculcation of values among students of three different 
incomes groups. This indicates that family's incomes do have significant impact on students' responses towards History learning. In addition, this finding shows a significant difference on the component of inculcation of values based on parents' occupations with the F values $=4.57$ and sig $=0.011(\mathrm{p}<0.05)$ among parents' who are working at the government sectors, private sectors and selfemployment.

\section{Research question 7}

Is there any significant relation among contents of History text book component, components of History pedagogy, inculcation of values, teaching aids and assessment with unity component?

Table 4.3 correlation among contents of History text book, History pedagogy, inculcation of values, teaching aids, and assessment with cultural unity

\begin{tabular}{|c|c|c|c|}
\hline components & \multicolumn{2}{|c|}{ Components of unity } & Strength of relationship \\
\hline Contents of History text book & 0.76 & 0.000 & Very high \\
\hline History pedagogy & 0.68 & 0.000 & high \\
\hline Inculcation of values & 0.83 & 0.000 & Very high \\
\hline Teaching aids & 0.66 & 0.000 & high \\
\hline Assessment & 0.74 & 0.000 & Very high \\
\hline
\end{tabular}

Based on Table 4.3 above, it shows that the level of relation among contents of History text book, inculcation of values and assessment is very high towards the efforts for unity. Whereas the other components of pedagogy elements and teaching aids also show a high level of relationship. This determines that the curriculum components do contribute to the appreciation of values for unity among students. This phenomenon has significant impact on contribution predictor factor for every component towards the elements of unity as shown in the table.

\section{Research question 8}

Is there any significant contribution among contents of History text book component, Historypedagogy, inculcation of values, teachingaids and assessment towards unity component? 
Table 4.4 Regression of contribution among contents of History text book component, History pedagogy, inculcation of values, teaching aids and assessment towards cultural unity

\begin{tabular}{|c|c|c|c|c|c|c|c|}
\hline & \multicolumn{2}{|c|}{$\begin{array}{l}\text { Unstandardized Coef- } \\
\text { ficients }\end{array}$} & \multirow{2}{*}{$\begin{array}{c}\begin{array}{c}\text { Standardized } \\
\text { Coefficients }\end{array} \\
\text { Beta }\end{array}$} & \multirow[b]{2}{*}{$t$} & \multirow[b]{2}{*}{ Sig. } & \multirow[t]{2}{*}{ R2 } & \multirow{2}{*}{$\begin{array}{c}\text { Re- } \\
\text { gres- } \\
\text { sion }\end{array}$} \\
\hline & B & error & & & & & \\
\hline $\begin{array}{l}\text { Component of values inculca- } \\
\text { tion }\end{array}$ & 0.47 & 0.03 & 0.48 & 16.60 & 0.000 & 0.691 & $69.1 \%$ \\
\hline Assessment component & 0.19 & 0.03 & 0.19 & 7.23 & 0.000 & 0.726 & $3.5 \%$ \\
\hline $\begin{array}{l}\text { Content of text book compo- } \\
\text { nent }\end{array}$ & 0.17 & 0.04 & 0.13 & 4.62 & 0.000 & 0.736 & $0.9 \%$ \\
\hline Teaching aids component & 0.09 & 0.02 & 0.09 & 3.78 & 0.000 & 0.740 & $0.4 \%$ \\
\hline $\begin{array}{l}\text { Component of History peda- } \\
\text { gogy }\end{array}$ & 0.06 & 0.03 & 0.05 & 2.20 & 0.028 & 0.741 & $0.1 \%$ \\
\hline constant & 0.17 & 0.08 & & 2.29 & 0.022 & & \\
\hline
\end{tabular}

Based on Table 4.4 above, it clearly shows a significant contribution of values inculcation component towards appreciation of unity elements among students (69.1\%). Whereas the other curriculum components show a very low contribution. Thus, there are still a lot of weaknesses need to be reproached in teaching strategies, the usage of teaching aids, types of assessments and contents of the text book, which are still Malay centric and prone to political will.

\section{Discussion}

This study determines that History curriculum components from the aspects of pedagogy, teaching aids and assessments arestill facing challenges due to lack of teachers' innovation. Teachers are still teaching conventionally, in addition to lack of creativity, irrelevant teaching medium to deliver the lesson and understanding. This fact was discussed by other History researchers such as a few studies done by Warti Kimi (1999), Khadijah Ahmad (2002) and Marsan Osman (1999), on teachers' weaknesses in preparation of teaching aids, the infamous cut and paste practice in setting questions items and also stereotypes of teaching

However, if it is viewed from the level of students' awareness on racial unity, there is indeed a significant awareness based on previous knowledge and students' experience. Thus, strengthening efforts are needed especially on lesson development by using multiple resources and teaching aids. In addition, this survey also identifies that students from the south zone have better adaptation ability in History class compared to students of other zones. This might be due to advance development of information access facilities and infrastructures in the south zone, whereas students from the northern zone show a rather passive learning response.

This study also found that there is a signifant difference on curriculum components based on gender. However, both male and female students have 
different opinions and responses on contents of the text book, inculcation of values, pedagogy, teaching aids and assessment. Female students' response on the aspect of interaction with the text book content is more consistent and showa better adaptation ability. The same finding is shown in the aspects of inculcation of values, teaching aids and assessment. Whereas, the male students show a more positive response on the pedagogy aspect. Test results of correlation and regression show a strong level of relation between inculcation of values with the elements of unity, at $69 \%$ of contribution. This finding contradicts with the other components which show a low level of relation with a little contribution.

\section{Conclusion}

This study clearly determines the importance of teaching and learning History as the main channel to mould the values and unity elements among students. Inculcation of values component should be functionalised actively to generate the elements of unity creatively in the History curriculum. Contents of the text book need to be reviewed in order to realise the government's mission and vision to uplift History curriculum as themain agent of racial unity and national integration. Reviewing text book will reform several elements to be less malaycentric and reshifted from the political discussion. In addition, this study identifies that in order to put forward better impacts, components of text book content, pedagogy, teaching aids and assessment do need major improvement. 


\section{REFERENCES:}

Abdullah, A.S. (1998). Perubahan dan hala tuju kurikulum sejarah. Kertas Kerja Simposium Kebangsaan Ilmu Sejarah. 30-31Oktober 1998. Anjuran J abatan Sejarah Universiti Malaya.

Ahmad, K. Hj. (2002). Tahap pemahaman konsep dalam pembelajaran Sejarah. Tesis Sarjana: UKM

Arthur, J ., \& Wright, D. (2001). Teaching citizenship in the secondary school. London: Fulton.

Borwell, C. \& .Eison. (1991). Creating Excitement in the Classroom. ASHE-ERIC Higher Education Report No.1.

Booth, M. (1980). A modern world history courseand the thinking of adolescent pupils. Educational Review. 32(3), 245-257

Furnival. (1956), Kajian Tentang Kepelbagaian Etnikdan Budaya. Boston: Allyn \& Bacon

Hussein Hj. A. (1985), Penggubalan Kurikulum Baru Sekolah Menengah. Pendidik dan Pendidikan 7, 1-11.

Hashim, O. (1992). Falsafah pendidikan Sejarah: Sejarah dalam pendidikan. Persatuan Sejarah Malaysia, Dewan Bahasa dan Pustaka. Kuala Lumpur.

Kementerian Pelajaran Malaysia. (2002). Huraian Sukatan Pelajaran Sejarah KBSM Tingkatan 1,2 dan 3. Pusat Perkembangan Kurikulum. Kementerian Pelajaran Malaysia.

Kember, D., K, K-P. \& Ledesma, J . (2001). Conceptions of good teaching and how they influence the way adults and school leavers are taught. International J ournal Of Lifelong Education, 20(5), 393-404.

Kimi, K. (1999). Kajian mengenai pengaruh, sikap, kemahiran dan pengetahuan dalam pelaksanaan pengajaran Guru Sejarah KBSM. Tesis Sarjana: UKM

Kirschner, P.A., Sweeler. J ., Clark, R.E. (2006). Why minimal guidance during instruction does not work. analysis of failure of constructivist, discovery, problem-based, experiential and inquiry-based teaching. Educational Psychologist, 41(2). 75-86.

Laughlin, M. A., \& Hartoonian, H. M. (1995). Challenges of social studies instruction inmiddle and high schools. Fort Worth, TX: Harcourt.

Meyers, C. \& J ones, T.B. (1993). Promoting active learning: Strategies for the college classroom. San Francisco: J ossey-Bass.

Mayer, R. (2004). Should there be a three rule against pure discovery learning. The case for guided methods of instruction. American Psychologist 59(1), 1419. 
Surya, M. (2004). Psikologi Pembelajaran dan Pengajaran. Bandung: Pustaka Bani Qurais.

Rashid, A. (2000). Model dan pendekatan pengajaran sejarah KBSM. Kuala Lumpur. Dewan Bahasa dan Pustaka.

Rillero, P. (1994). Doing science with your children.Available:http:npin.org/ library/ pre1998/n00240.html

Stufflebeam, D.L., A.J . (2007). Evaluation theory, models and applications. 1ed. San Francisco: J osey-Bass A Wiley Imprint.

Toh Wah Seng. (2008). Buku Koleksi Bahan Seminar Inovasi Pedagogi IPBL Tahun 2008. Pedagogi pembelajaran aktif dalam p\&p Ekonomi ke arah membangunkan modal insan.

Weiner, R.G. (1995). History: teaching and methods. ED 387402 (Eric Document Reproduction service) 